\title{
Koi Gyula
}

\section{Gérard Marcou és az összehasonlító közigazgatási anyagi és eljárásjog II.}

Rendszerek frankofón hatás alatt; a germán, skandináv, angolszász, posztszocialista, ázsiai és afrikai rendszerek példája ${ }^{1}$

\section{Gérard Marcou and the Comparative Substantive and Procedural Administrative Laws II.}

Systems under Francophone Influence; and German, Nordic, Anglo-Saxon, Post-Socialist, Asian and African Systems

\section{Összefoglalás}

Jelen tanulmány célja a néhai francia közigazgatási jogi professzor, Gérard Marcou életmúvének bemutatása és elemzése, elôtérbe állítva a róla szóló emlékkötetet, továbbá reflektál az ezen monográfiába foglalt tudományos tételekre. Nyilván kevéssé lenne értelemteljes a mú egy rövidebb kivonatát parafrázisszerúen közreadni, mintegy megcsonkítva azt. Tanulmányunk az összehasonlító közigazgatási anyagi és eljárásjogi elemekre fókuszál, a frankofón hatás alatt fejlődött országokat, és a germán, skandináv, angolszász, posztszocialista, ázsiai és afrikai rendszerek kérdésköreit vizsgálva.

Dr. Koi Gyula tudományos munkatárs, Eötvös Loránd Kutatási Hálózat, Jogtudományi Intézet (Koi.Gyula@uni-nke.hu). 
Koi Gyula: Gérard Marcou és az összehasonlitó közigazgatási anyagi és eljárásjog II.

Kulcsszavak: afrikai jog, angolszász jogrendszer, ázsiai jog, frankofón jogrendszer, gazdasági jog, germán jogrendszer, Gérard Marcou, helyi önkormányzat, kínai közigazgatási jog, közigazgatási bíráskodás, közigazgatási jog, orosz közigazgatási jog, posztszocialista jogrendszerek, skandináv jog

\section{Summary}

The main purpose of this paper is to present and analyse the oeuvre of the late French professor of administrative law, Gérard Marcou, to highlight his "Liber Amicorum", and to outline the scholarly theses of this monograph with focus on the elements of comparative substantive and procedural administrative law, and gives examples of systems under Francophone influence, and outlines the German, Nordic, Anglo-Saxon, postsocialist, Asian and African Systems.

Keywords: African law, Anglo-Saxon legal system, Asian law, French-speaking legal systems, business law, German legal systems, Gérard Marcou, local self-government, Chinese administrative law, administrative jurisdiction, administrative law, Russian administrative law, post-socialist legal systems, Nordic law

A FRANKOFÓN RENDSZER II.:

A FRANGIA HATÁS ALATT FEJLÓdÖTT OLASZ, SPANYOL, PORTUGÁL，GÖRÖG ÉS EGYÉB IGAZGATÁSI REZSIMEK

Luciano Vandelli, a Bolognai Egyetem docense közigazgatási jogból, illetve Marzia De Donno, a Ferrarai Egyetem Jogi Tanszékének docense a francia és az olasz decentralizációs tendenciákat veti össze. Ennek címe: Évolutions de la décentralisation en France et en Italie: un regard comparé(Perroud, 2017:445-458). A szerzók a francia és az olasz összehasonlítás példáját a fejlődés bizonyítékaként vizsgálják. A decentralizációs intézményeket a közigazgatási rendszerek összetettségének példájaként tárják elénk. Mindkét igazgatás vonatkozásában kiemelhetố az Európai Unió (és joga) közvetlen hatása. A szerzók külön is kiemelik a francia közigazgatás hatását az olasz, a spanyol, a portugál és a görög közigazgatásra. A francia és az olasz közigazgatás is forradalmi-napóleoni eredetú. A szerzók nagyjából hasonlóképpen írják le a nagyvárosok (métropole) igazgatásának helyzetét. A 2014-es francia törvény a közpolitika modernizálását jelentette, megerôsítve Párizs, Lyon és Aix-Marseille-Provence pozícióját. Az olasz helyzet másként alakult, fóleg az alkotmánymódosítások kapcsán. A 2001-es módosítás hozta a helyi önkormányzatiságra vonatkozó változtatást (114. cikkely). 2014-ben a nagyvárosok helyzetét külön törvény szabályozta. Az egyéb részletekkel a tanulmány további részei foglalkoznak.

Fernando López Ramón, a Zaragozai Egyetem Közigazgatási Jogi Tanszékének oktatója a közrend és a spanyol demokrácia kapcsolatáról írta spanyol nyelven esszéjét Las obras públicas en la democracia española (Perroud, 2017:859-868). A szerzó a témát fóleg az állami közlekedési vállalatok (RENFE, FEVE, Iberia) és állami médiák/ 
kommunikációs társaságok (CTNE, RTVE) példáján keresztül tekinti át. E változások fontos szakasza volt az 1982 és 1996 közötti időszak, illetve kiemelten Spanyolország uniós csatlakozása (ingreso) 1986-ban. A kérdéskört a stratégiai tervezés (planificación estratégica), a pénzügyi tervezés (ingeniería financiera), a várostervezés (licencia urbanística), illetve a környezetvédelem (protección ambiental) szempontjából vizsgálja. A dolgozatban kiemelt szerep jut az autonóm közösségeknek, a községi/városi urbanisztikai tervezésnek és a Bolkenstein-direktívának (2006) vagy szolgáltatási, más néven belsô piaci irányelvnek (2006/123/EK irányelv).

Miguel Sánchez Morón, az Alcalái Egyetem Közigazgatási Jogi Tanszékének oktatója a spanyol közszerződési joganyagra vonatkozó, speciális közigazgatási jogorvoslat tárgyában tette közzé spanyol nyelvú munkáját: El recurso administrativo especial en materia de contratación pública en España (Perroud, 2017:995-1004). Meglátása szerint az európai uniós jogban, a közszerződések (contratación pública) körében legfontosabb a szerepe az alkalmazható (hasznos) és hatékony jogorvoslatnak (recurso útil y eficaz), illetve a bírói döntésnek (adjudicación). A független közigazgatási szervek (órgano administrativo independiente) és bírói szervek (órgano judícial) tevékenysége nyomán számos ügyet bíráltak el a témakörben (Alcatel Austria, 1999; Universale Bau, 2002; Michaniki, 2003; Bizottság kontra Írország, 2010). A közszektor szerzódéseirôl szóló 3/2011 (XI. 14.) királyi rendelet inkább a kérdés közigazgatási és kevésbé jogi természetét emelte ki. A jogorvoslatok serény és hatékony (recurso ágil y efectivo) módon történô alkalmazása jellemzi a spanyol jogot. A különös jogorvoslatok (recurso especial) fó jellemzôje a teljes funkcionális függetlenség (plena independencia funcional) a hatáskör gyakorlása tekintetében (en el ejercicio de sus competencias).

Florence Lerique, a Bordeaux-i Montaigne Egyetem professzora anyagának témája a baszk városiasodás tendenciáit tekintette át La compétence urbanisme dans les EPCI XXL: le cas de pays Basque (Perroud, 2017:269-275) címmel. Az új változások úgyszólván átírták a közigazgatási térképet, baszk vonatkozásokban. Az 1990-es évek végén ennek a helyi közpolitika változásai ágyaztak meg. Egy 1999-es törvény meg is növelte a baszk terület jelentőségét. A 2015-ös év törvényi változásai a városiasodással kapcsolatos hatásköröket rendezték (vö. ehhez az 1999-es törvény adóügyi rendelkezéseit, illetve Lille nagyvárosi fejlôdését, ideértve a környékbeli nyolcvan községet is). Nagy-Párizs, Lyon és Aix-Marseille-Provence, továbbá Nizza nagyvárosi helyzete volt a példa a baszk fejlôdés számára is.

Théodore Fortsakis a görög alkotmányos kihívásokat a parlamenti jegyzókönyvek tartalmiságát illetôen vizsgálja: Les mémorandums en Grèce: un défi pour la Constitution (Perroud, 2017:1061-1074). A gazdasági válság nagy erôvel sújtott le Görögországra 2009-ben. Ezek a problémák a gazdaságra és a közigazgatásra is kihatottak. A pénzügyi segítség Görögország európai partnereitôl és az IMF-tôl jött. Az e tárgyban írt három parlamenti jegyzôkönyv tanulságait foglalja össze 2012 és 2015 közöttról a válság vonatkozásában, különös tekintettel a privatizációs „szuperkassza” ügyére. 2015. július 15-tôl datálódik a szuperkassza (Görög Részvétel és Örökség Társaság Részvénytársasága), amely a magánosításból eredô állami bevételt foglalja magában (a görög adósságállomány csökkentése céljából), ennek indulótőkéje 40 millió euró volt. 
Koi Gyula: Gérard Marcou és az összehasonlító közigazgatási anyagi és eljárásjog II.

Fernando Menezes de Almeida, a São Pauló-i Egyetem Jogi Karának professzora dolgozatát a brazil jogintézmények és felsôoktatási-tudományos rendszer, valamint a frankofón szisztéma kapcsolatáról írta. Ennek címe: La francophonie pour façonner les institutions juridiques et académiques au Brésil (Perroud, 2017:13-24). A tanulmány a portugál (és ezáltal francia) mintára szervezett brazil felsôoktatási rendszert tekinti át, kiemelten jogelméleti és közigazgatási jogi szempontokból. A francia modell hatásai már Brazília 1822-es függetlenné válásával kimutatható volt, 1827-ben került sor a São Pauló-i Egyetem Jogi Karának megalapítására. Mind a közjogban, mind az oktatás és kutatás (azaz az elméleti tudománymúvelés, az „akadémia”) világában a francia hatások érvényesültek (többségében portugál közvetítéssel). A császárkori Brazíliában a francia kettôs igazságszolgáltatási rendszert vették át, melynek élén az Államtanács állt, az állam unitárius és centralizált volt. A köztársasági Brazília az angol-amerikai jogi gondolkodás felé fordulás irányába, ezáltal az egységes bíráskodási rendszer, illetve a föderális állam és az elnöki köztársaság felé mozdult el. Azonban a közigazgatási jogban a francia hatások a 20. század elsô évtizedeiben is jelen voltak. Ez a legkorábbi brazil közigazgatási jogi munkákból kimutatható. Vincente Pereira do Rego 1860-as múve (Elementos de direito administrativo brasilero) az egyik alcímben pontosítja, hogy könyve „összehasonlítás a francia közigazgatási joggal, P. Pradier Fodéré ${ }^{2}$ módszere alapján”. Antonio Joaqim Ribas múve (Direito administrativo brasilero), mely 1861-ben keletkezett, 51 munkát idéz, ebból 36 a francia. A mú érdekessége, hogy a bibliográfia elôször a brazil, utána a francia, ezt követôen az egyéb európai szerzôk munkáit sorolja fel. Ebben a múben utal az egyik legkorábbi francia közigazgatásijog-múvelôre, De Gérandóra (Koi, 2014:75-76). Visconde do Uruguai, azaz Paulino José Soares de Souza 1862-es munkája (Ensaio sobre o direito administrativo) által idézett 111 mú közül 68 francia jogász vagy filozófus munkája volt. Napjaink tapasztalatai a brazil közigazgatási jogban a francia hatások mellett az „élenjáró” észak-amerikai közigazgatási jog hatásai dominálnak. Brazíliában jelenleg is komoly elméleti vita folyik a közigazgatási jog és a közigazgatás sajátos jellegérôl (caractère spécial) és filozófiai alapjairól, hasonlóan a francia Közszolgáltatási Iskola (École du service public) vagy toulouse-i iskola, illetve a Közhatalmi Iskola (École de la puissance publique) vagy bordeaux-i iskola képviselôi között (Koi, 2014:253-262). Almeida rámutat, hogy a Közhatalmi Iskolát Léon Duguit, illetve Gaston Jèze képviselték. (Említendô azonban, hogy a Közszolgáltatási Iskola feje Maurice Hauriou volt, a vita pedig nagyjából 1890 és 1940 között folyt.) A brazil közigazgatási jog fogalomadásait (notions) a mai napig befolyásolja a francia tudományosság.

Eduardo Jordão, a Rio de Janeiró-i Egyetem Jogi Karának professzora, aki PhD-fokozatát Marcounál szerezte francia nyelvú disszertációval (Jordão, 2016), jelen kötetben a bírósági felülvizsgálat és a globalizáció kapcsolatát vizsgálta Brazília példáján keresztül angol nyelvú tanulmányában. Ennek címe: Globalisation and convergence in judicial review: what can we learn from the case of Brazil? (Perroud, 2017:843-850) A kérdést az összehasonlító közigazgatás aktuális témájának (hot topic) tartja. Ennek ellenére igen csekély a témával foglalkozó komparatív közigazgatási jogi munkák száma. A 19. századtól jelen volt a francia közigazgatási jogban okozott kár. A késóbbiekben a fran- 
cia jogban az egyéni prerogatívák száma nôtt, bár a szerzố szerint ez nem angolszász hatásnak tudható be. Alberti elmélete nyomán a diszkrecionárius közigazgatás hatalmának csökkenésével számol globálisan a piacszabályozás terén. Nagyon érdekes az az utalás, amely szerint a francia Államtanács (Conseil d'État) (köz)hatalommal való viszszaélés (abuse of power, détournement de pouvoir) tárgyában alkotott 1875. november 26-i döntésének (Baulny-Laferrière, 1875) ${ }^{3}$ érvelése egy 1941-es brazil helyi bíróság által lett a brazil jog részévé. Gaston Jèze ${ }^{4}$ által alkotott meghatározó okok elmélete (doctrine des motifs déterminants; manifest error of assessments; teoria dos motivos determinantes) hatott a francia közigazgatási esetjog brazil recepciójára. 1944-ben a brazil Szövetségi Legfelsôbb Bíróság (Supremo Tribunal Federal) sem tért le erról az útról. A francia jogból került át a nyilvánvaló mérlegelési hiba (erreur manifeste d’appréciation; manifest error of assessment) doktrínája is, amely az 1988-as brazil alkotmány részévé vált (érdekesség, hogy a hatályos francia jog már nem alkalmazza). A jogbiztonság (legal certainty), valamint az arányosság elve (principle of proportionality) a német közigazgatási jogból; a merito, azaz a legitimitás elve, valamint a technikai mérlegelés (technical discretion) az olasz közigazgatási jogból került a brazil közigazgatási jogba.

Carlos Ari Sundfeld, a São Pauló-i Egyetem Jogi Karának címzetes professzora, a Brazil Közjogi Társaság elnöke az állam mint szerzôdố fél szerepérôl alkotta meg eszszéjét a brazil jog tükrében. Múve címe: Le droit administratif dans l'incertitude: le contrôle de l'État contractant au Brésil (Perroud, 2017:1005-1022). A jog feladata a biztonság, a vállalatok és a gazdaság múködésének megórzése - íme egy elkoptatott, de a brazil egyetemek mindegyikén oktatott gondolat Sundfeld szerint. Az eltérô hangsúlyok között is fontos kérdés az állam által kötött szerződések jelentőségének megértése. A brazil Számvevôszék mellett múködô Számvevôszéki Bíróság nem minôsül a brazil jog szerint igazságszolgáltató szervnek, csupán állami szervnek, nem jogi eljárásai mégis meghatározzák az állam által kötött szerzôdések teljesítési szabályait. A dolgozat többi része az állami vállalatok szerzôdéses folyamatait, a szerzôdéses folyamatokra vonatkozó jogi szabályozás és jogviták irányát vizsgálja.

Grenfieth de Jesus Sierra Cadena, a bogotai Del Rosario Egyetemen az összehasonlító jog oktatója az egyén szerepét vizsgálta az EUB és az Andoki Közösségi Törvényszék (Tribunal de Justice de la Communauté Andine) ítélkezési gyakorlata tükrében. Címe: L'individu devant le Tribunal de Justice de la Communauté Andine et la Cour de Justice de l'Union Européenne: une approche comparée à l'âge de l'internationalisation pluraliste de droit (Perroud, 2017:35-54). A szerzô elvi kiindulása nem egyéb, mint a jog sokszínúségének és nemzetköziesedésének elmélete (internalisation pluraliste du droit). A nemzetköziesedési eljárás, folyamat legjelentősebb karaktereleme (caractéristique) egyfelől a jog egysége és egységessé tétele (homogenizációja), másfelől a sokszínúség és a jogrendszerek különbözôsége, azaz a két eltérô nézetrendszer között feszülô ellentét maga. Mindez elképzelhetô, hogy egy új jogi pluralizmus irányába mutató fejlôdés jele. A jog sokszínúsége és nemzetköziesedése újdonságnak számít a latin-amerikai államokban. Egyesek történeti elóképnek tekintik a térség vonatkozásában a spanyol császárok által alkotott kelet-indiai ${ }^{5}$ jogot, amely tágabb értelemben egy 16-19. századi konstrukció. Ennek a jognak az alábbi jellemzói voltak: jogi pluralizmus, amely 
Koi Gyula: Gérard Marcou és az összehasonlitó közigazgatási anyagi és eljárásjog II.

a jogforrások egységét és „örökkévalóságát” jelentette; méltányosságon alapuló, azaz „prétori” jogi produktum, mely széles mozgásteret enged a helyi bírák számára; területi igazgatási típusú közjogi szabályok; az idegenek és azok tulajdonát védó jogi szabályozás; személyre tekintettel lévô, kazuisztikus jogértelmezés és jogalkalmazás; inkább a természetjogon, semmint a tételes jogon alapuló szabályozás. Az írás a továbbiakban áttekinti a címben jelzett két bíróság gyakorlatában a gazdasági szabadság garanciái és a versenyjogi normatív szabályozás jelentôségét; az egyén szerepét az EUB és az Andoki Közösségi Törvényszék gyakorlatában. Az utóbbi összehasonlításban a közösségi jog alkalmazhatóságát vizsgáló francia Államtanács Nicolo-ügyben (1989) hozott döntésének hatását emeli ki, különös tekintettel az elôzetes visszautalás (renvoi préjudiciel) vonatkozásában. Külön szerepet kap a személyek védelme a két bíróság gyakorlatában. Jelentôséget tulajdonít a jogszerúségi felülvizsgálatnak a nemzetek feletti (szupranacionális) bíróságok elôtt. Idesorolható az érvénytelenítésre irányuló felülvizsgálat (recours en annulation), a jogsértés megállapítására irányuló felülvizsgálat (recours en manquement) kérdése is. A szerzô szerint a nemzeti pluralizmusok harmonizációja körében a prejudiciális kérdések tisztázásának kiemelt a szerepe.

\section{A GERMÁN RENDSZER}

Anne Jacquemet-Gauché, az Auvergne-i Egyetem Közjogi Tanszékének professzora a német dologi jog kérdéseit vette górcsó alá. Az írás címe: Qu'est-ce qu’une 'bonne question'? À propos du droit allemand des biens publics (Perroud, 2017:831-842). A tanulmány a „jó kérdés” tudományos szerepét elemzi, ideértve a jó kérdésfeltevés jelentôségét is. Kiemeli a közjavak (biens publics) francia doktrínájának jelentőségét a német jogban. E témakört a különös részi közigazgatásba vagy szakigazgatásba (droit administratif spé(ial) is beemelték, hozzátéve azt az elvi tételt is, hogy a közigazgatási jog konkretizált alkotmányjog (konkretisiertes Verfassungsrecht; droit constitutionnel concrétisé), azaz a közigazgatási jog az alkotmány (az alkotmányjog) gyakorlata. ${ }^{6}$ Azonban utal rá, hogy a német jogban ma a közjavak doktrinájának francia eredetére talán kevesebb figyelem vetül (megjegyezzük, hogy a közigazgatási jog és a magánjog efféle határkérdéseinél - mint minden határterület esetében - gyakran kevésbé tisztázottak az elmélettörténeti alapok, mint a csupán egyetlen nagy jogág területére tartozó fó jogintézmények esetében). Helyesen utal Jacques Ziller 1993-as, Administration comparée címú ismert alapmúvében leírt szavakra, mely szerint: „Az állami javakra vonatkozó összehasonlító jog felismerése már megtörtént... majd nem sokkal ezután sokkal jobban kifejlôdött Németországban, mint Franciaországban, ugyanis a németek sokkal nagyobb mesterei a francia dologi közigazgatási jognak, mint a franciák a német [közigazgatási - $K$. Gy.] jognak."7 Véleményünk az, hogy általánosságban a közigazgatási jogban a francia és a német tudományosság kapcsolata ${ }^{8}$ kulcskérdés, oda-vissza nyúlnak a kapcsolatok szálai a klasszikus és a mai közigazgatási jogtudósok között. Elég arra utalni, hogy a legnagyobb német közigazgatási jogász, a Strasbourgban tanult, franciául aggálytalanul tudó, a francia közigazgatási jogot már joghallgatóként is tanulmányozó Otto Mayer kezdetben a francia közigazgatási jog teóriáját foglalta össze németül 1886-ban, 
és ezután tudta csak megalkotni a föderális német államok számára a német közigazgatásijog-dogmatikát 1895-1896-ban. Ugyanakkor francia szerzók (többnyire francia közigazgatási jogról szóló) munkáit is lefordították németre, például Gaston Jèze francia közigazgatási jogról szóló könyvét 1913-ban (Koi, 2014:46-55, 69-96, 253-266). Illetve természetszerúleg ma is foglalkoznak egyes francia közigazgatási jogászok a német, egyes német közigazgatási jogászok a francia joggal. Viszont a fenti szöveg - mivel rendkívül elismert francia múvelôtôl származó kinyilatkoztatás - rendkívüli értékkel bír. A tanulmány többi része a közjavakkal és a köztulajdonnal kapcsolatos szervezési kérdésekkel, illetve a közjogi jogi személyiségre vonatkozó tematikával, illetóleg a magánosítás, valamint a közjavak magánosításával foglalkozik.

Michael Thaler, a Salzburgi Egyetem Alkotmány-és Közigazgatási Jogi Tanszékének professor emeritusa az osztrák alkotmánybíráskodás reformjáról tette közzé dolgozatát. Címe: La réforme de la justice administrative autrichienne (Perroud, 2017:1019-1026). Ennek jelentôsége abban áll, hogy egyes jogintézményeket az új hazai közigazgatási eljárási törvény, az Általános Közigazgatási Rendtartás (2016. évi CL. törvény) az osztrák szabályozásból emelt át. Az osztrák közigazgatási bíráskodás (justice administrative autrichienne) reformjának eredménye 2014. január 1-jével lépett hatályba. A szerzô ismerteti a közigazgatási bíráskodás három lehetséges ideáltipikus (idéaux-types) rendszerét. Az elsố rendszer, amikor a közigazgatási pereket a rendes bírósági rendszeren belül bírálják el. A második rendszer, mikor a közigazgatás ellenőrzése a közigazgatási rendszeren belül marad. A harmadik rendszer, amikor a független közigazgatási bíráskodáson belül egy köztes megoldás valósul meg. A közigazgatás ellenôrzése, kontrollja nem valósul meg a végrehajtó hatalom által önmagában, hanem a közigazgatási bíráskodás segítsége által, azon belül speciálisan létrehozott, különálló, adott szempontok szerint szervezett, egyszerre közigazgatási és igazságszolgáltató szerv által megy teljesedésbe. Az Osztrák Szövetségi Alkotmány 18. szakasza kimondja: „Az államigazgatás egésze a törvénynek alárendelten múködik.”9 A közigazgatási eljárás a közigazgatási eljárási törvény által múködik. Ez a jogvitás eljárások, jelen esetben a fellebbezés (Instanzenzug; instances contentieuses) természetéból ered. Mindezt a közigazgatási hatóságok rendszere támogatja igazságszolgáltatási formákba öltözötten. Ha a fél úgy érzi, hogy a döntés alanyi jogát (droit subjectif) sérti, a magasabb közigazgatási szintre fellebbezhet. Az ilyesfajta közigazgatási eljárás célja a közigazgatás saját cselekményeinek (aktusainak) ellenôrzése. Az ilyesfajta kontenciózus eljárás nem csak az alanyi jogot sértô döntések megsemmisítésére irányulhat. Ezzel egyidejûleg biztosítani kell minden lehetô módon és jogi eszközzel, hogy a jogellenes döntéseket hatályukban ne tartsák fenn (des decisions illégales ne se maintiennent pas durablement), mivel azok mérgezett almák módjára a jogrendszert megsemmisítik, elrothasztják. Az osztrák jog egyes általános elvei közül a közigazgatási szerzôdések körében a személyes önrendelkezés (Privatautonomie; autorégulation) elve emelendô ki. Az osztrák közigazgatási eljárás ugyanakkor rengeteg kérdést vett fel, melyeket a tanulmány utolsó része vizsgál.

Peter M. Huber, a Müncheni Egyetem professzora, a karlsruhei német alkotmánybíróság (Bundesverfassungsgericht) alkotmánybírája, a kötet egyik legelismertebb szerzője német nyelvú tanulmányát Demokratische Selbstbestimmung als neuer „rocher de 
Koi Gyula: Gérard Marcou és az összehasonlító közigazgatási anyagi és eljárásjog II.

bronze" des deutschen Staatsrechts címmel (Perroud, 2017:1075-1082) a német új, gránitszilárdságú (rocher de bronze) közjog (pontosabban államjog - Staatsrecht) tematikáján belül a demokratikus (helyi) önrendelkezésnek (demokratische Selbstbestimmung) szentelte. A német tanulmány címében olvasható francia kifejezés német értelme (eherner Fels) ércsziklát, átvitt értelemben rendíthetetlen kósziklát jelent. A francia rocher de bronze kifejezés bronze tagja is jelent ércet (és nem csak bronzot). Magam a rendelkezésemre álló francia egynyelvú szótárakban és etimológiai szótárakban ${ }^{10}$ nem találtam a kifejezést. A francia ${ }^{11}$ szóösszetételt Frigyes Vilmos porosz király használta egy lapszéli kéziratos jegyzetszövegben 1716. április 25-én. ${ }^{12}$ Ez a porosz junkernemesség adóemelés elleni tiltakozásának letörésével, a nemesi szabadság korlátozásával állott összefüggésben. Értelem szerint a tanulmány szövegében inkább gránitszilárdságúként adtuk vissza, mivel a szó szerinti jelentése a magyar gondolkodásnak világosabban befogadható. A demokratikus önrendelkezés kollektív és egyéni felfogása átlengi a tanulmányt. Az önrendelkezés összetett fogalom (vielschichtiger Begriff). Példákként történetileg Ernest Renan, Pico della Mirandola, illetve az USA Függetlenségi nyilatkozata köréből hoz példákat. A német alkotmányban jelentkezô demokratizmus elve (Demokratieprinzip) a közigazgatási szervezeti jog gránitszilárdságú fejlôdésében az állam és az alkotmány újfajta megértését jelenti. A demokratizmus követelménye (Anspruch auf Demokratie) jelentkezik mind az EU-bíróságok, mind a Bundesverfassungsgericht gyakorlatában, még ha az európai jogtudományban a demokrácia melléktéma is (juristisches Randthema), ugyanakkor a demokráciáról Európában (politikai) viták folynak.

Oswald Jansen, a Maastrichti Egyetem európai közigazgatási és közigazgatási jogi professzora, Hága város önkormányzatának jogi tanácsadója és ügyvédje a holland önkormányzatok közigazgatási büntetôjogi (szabálysértési), büntetô jellegú szankciói kérdését dolgozta fel. A múve címe: Sanctions punitives par les autorités locales aux Pays-Bas. Quelques développements récents (Perroud, 2017:223-242). A magyarban bagatell búncselekményeknek is hívott, közigazgatási büntetôjogi vagy szabálysértések, kisebb súlyú cselekmények feldolgozása (désagréments mineurs) Hága és Amszterdam vonatkozásában történik, különös tekintettel a 2016. június 22-i szabályozásra. Hollandiában nagy vita folyt a büntetési módozatokról, illetve a közigazgatási szankciókról és a közigazgatási bírságról (bestuurlijke boete; amende administratif). A közigazgatási bíróság szerepe növekszik a gazdasági és pénzügyi jog területére tartozó független közigazgatási szervek vonatkozásában is. A vita a közigazgatási rendszer és a büntetôjogi szankciórendszer összehasonlításának szükségességét hozta felszínre. A tanulmány további részei a holland területi közigazgatás szervezetét, illetve a közrendfenntartás tapasztalatait tekinti át. E körben kiemelt szerepet kap a büntetójogi rend (strafbeschikking; ordonnance pénale), az adminisztratív pönalizálás (pénalité administratives), a helyreállító szankciók (herstelsancties; sanctions réparatrices), illetve a különféle ellenôrök (toezichthouders; contrôleurs) szerepének ismertetése. Külön pont a büntetőjog és a polgári jog alkalmazása a kérdés vonatkozásában. Ugyanígy szerepet kap a helyi önkormányzati közigazgatási büntetójog (pénalité administrative aux mains de l'administration locale). 


\section{A SKANDINÁV RENDSZER}

Lena Marcusson, az Uppsalai Egyetem közigazgatási jogi professzora múvét a jogi közigazgatás és a felelôs közszolgálat témakörében alkotta meg angol nyelven. Írása címe: Good administration and responsible civil servants. A Swedish perspective (Perroud, 2017:869-876). A tanulmány utal az „egzotikus” nordikus jogi tradíciókra (Almén, 1922; Eörsi, 1974) ${ }^{13}$ és a (fóként a svédek esetében) eltéró közjogi hagyományokra (Tamás, 2011:549-574). A közigazgatási jogban a minisztériumi modellek egyik típusa a más északi országok által is átvett, ún. svéd minisztériumi modell (Lórincz, 2005:115-116), melynek lényege, hogy a klasszikus minisztériumi modell politikai, illetóleg adminisztratív kettôs jellegét megszüntette. A minisztérium kis létszámú, fiatal, dinamikus személyzettel (minisztériumonként átlag százfőnyi köztisztviselő) dolgozik; a végrehajtást, a tulajdonképpeni adminisztrációt pedig az idôsebb, tapasztaltabb személyzettel rendelkezô, autonóm hatóságok látják el (akár 1200 fố is dolgozhat egy hatóságnál). Gérard Marcou összehasonlító kutatásaira utalva, Marcusson új adatokkal lát el bennünket. 200 fố dolgozik jelenleg a kifejezett minisztériumokban, és $4500 \mathrm{az}$ autonóm hatóságoknál, melyek száma jelenleg 20. (A minisztériumok száma 1990-ben 13, jelenleg 11). A kormányzati közügyeket az utóbbi három évtizedben a New Public Management eszméi szerint vitték. A célalapú és az eredménymérést elônyben részesítô kormányzást kombinálták a felmérésekkel, az ellenôrzéssel és a jelentéstétellel. (És hozzátenném, hogy a teljesítményalapú illetmény mellett megjelentek a közszolgálatban lévô „kiváltságok” és a közszolgálati jogias szabályozás helyett az egyszerú munkaszerzôdéssel történố foglalkoztatás, a közigazgatás lenézése a „mindentudó” multinacionális vállalatok munkavállalóival szemben.) Fontos volt (és egyébként maradt is) a közfeladat, a felelôsség (responsibility), illetve az elszámoltathatóság (accountability) kérdése, bár megjegyezném, az NPM bukását (néhány „szamurájtermészetû” ausztrál és új-zélandi közigazgatás-tudóst kivéve) mindenki befejezett ténynek tekinti. Az „NPM után” kérdésére a szerzố válasza az erôs kormányzással szembeni kritika. 2014-ben kutatás kezdôdött a foglalkoztatási rendszer megváltoztatására. Végül is 2016-ra a közügyek körében a szakmai delegálás megoldását tartják jónak. A helyi és regionális igazgatás (local and regional administration) szerepe felértékelődik, szemben a (kifejezett központi és középszintû) államigazgatással (state administration) a közoktatás, az egészségügyi igazgatás és szociális igazgatás terén. (Sajnálatos, hogy a szerzô az NPM utáni kérdést illetôen nem vet számot a New Public Service, illetve a Robert Denhardt-i New Weberian State jelenségével.)

\section{Az ANGOLSZÁSZ RENDSZEREK}

Thomas Perroud, a Paris II. (Panthéon-Assas) Egyetem professzora, Marcou egykori PhD-hallgató tanítványa a public trust fogalmiságának kérdésérôl tette közzé esszéjét. Ennek címe: Recherche sur un fondement de la domanialité publique dans les pays de common law: la notion de public trust (Perroud, 2017:951-966). A public trust fogalmiságát a tanulmány a kincstári közjavak (domanialité publique) körében tárgyalja. A trust fogalmát 
Koi Gyula: Gérard Marcou és az összehasonlitó közigazgatási anyagi és eljárásjog II.

az angol és az amerikai jog egyaránt ismeri, és szerepe részben visszavezethetô a köz és a magán leválasztására az angolszász jogrendszerben (common law system), szemben a kontinentális jogrendszerrel, melyet az angolszász jog civil law system formában nevez meg. (Mindez magyarázatra szorul: ez nem azt jelenti, hogy csak magánjog létezne a kontinentális jogban, hanem a megoldás a római jogi alapokban rejtezik, melyet latinul ius civilének is hívtak.) A trust doktrína eredete Angliában keresendő. A középkori Angliában, akár Európa többi részén, a kincstári javak a király és a húbérurak (seigneurs) kezelésében álltak. A folyók használatának szabadsága elé is akadályokat gördítettek. Henry de (Henricus) Bracton (olykor Bratton vagy Bretton alakban) (1210-1268) De legibus et consuetudinibus Angliae címú négykötetes múve (elsô fennmaradt kézirata: 1265) második kötetében a folyókról szóló problémakört az alábbiakban vázolja: „Valamennyi folyó és kikötô a közjavak körébe tartozik, így a halászati jog mindenki számára engedélyezett (szabad).” (Perroud által idézett francia szöveggel: „Toutes les rivières et les ports sont publics, si bien que le droit d'y pêcher appartient à tous.”) Perroud kimutatja azt is, hogy a 1215-ös Magna Charta Libertatum (la Grande Charte) számos cikke foglalkozott a folyók és az erdôk használatáról szóló, alapvetően hasonlóan engedố szabályozással. Azonban a common law és maga a szabadságlevél bizonyult a szabadságok elsố akadályozójának is. Ugyanis a 23. cikk megtiltotta a halgátak emelését (prohibait l'édification de barrage à poissons). Ez jelentette késôbb a hajózási szabadság megtiltásának kezdetét. Ugyanakkor a király számára is tiltva volt, hogy védelmi célból a (húbérúri) vízfolyásokat és vizeket elfoglalja, ez a halászat és a vízimadarak vadászati tilalmát is jelentette az adott vizeken. Azonban tény, hogy sem a Nagy Szabadságlevél, sem Bracton (ellentétes) álláspontja nem rejthette el a valóságot, mely alapján a tengerek és folyók köztulajdoni javai a húbérurak birtokában voltak. A Rex v. Clark ügyben Holt fóbíró mondta ki, hogy a hajózás megtiltása a Magna Charta Libertatummal ellentétes. A 17. században Lord Hale De Jure Maris címú, az Amerikai Egyesült Államok jogi gondolkodásra ható munkája nem kérdôjelezte meg a király azon jogát (hatalmát), hogy a folyók és a folyópartok hasznosítását magánszemélyekre ruházza át (céder). Hale a jus publicum, a jus privatum, illetve a jus regium kategóriáival dolgozik. Hale rendkívül érdekes megállapításokat tesz a jus publicum vonatkozásában. Itt a közérdeket és a közjogot azonosítja, mely alapján az emberek, a nép közérdekbôl eredô jogaként hivatkozott a dolgok vízi fuvarozására, és ezek visszaúton történô szállítására, továbbá arra, hogy egyes tulajdoni tárgyak szabad tulajdonlása (freehold) a népet illető közérdekből ered. A public trust kifejezés csupán a 19. századtól jelent meg. Joseph Angell arra mutatott rá, hogy a halászati jog és a hajózási jog vonatkozásában a király jogai (jogcímei) sem korlátlanok. Ezt hasonlóan értékelte Cromwell lord protector esetében is. Arra is rámutatott, hogy e jogok gyakorlása során a király csupán megbízott (trustee). Jan S. Stevens 1980-1981-es dolgozatában a 19. századi angol helyzetet akként magyarázza, hogy a fejlődés iránya a régi fogalomhasználat és az új fogalomhasználat mezsgyéjén mozgott. A 19. század volt e változás aranykora, amikor a közföldek elidegenítése magában foglalta a folyóágyak és a hajózható vízi útvonalak tereptárgyai átruházását is, megkülönböztetésmentesen. Jelentős a doktrína változásainak szemléltetése az Amerikai Egyesült Államok példáján, hasonlóan történeti 
kontextusban. A forradalommal a királyi hatalom megszúnt az USA területén, és ezeket a jogokat az amerikai nép képviselői útján gyakorolta. A Shively v. Bowlby (1894) ügyben a tengerpart köztulajdoni jogállása merült fel. A common law szerint ez nyilván a királyé, aki csak önkéntes jogcímmel ruházhatja át magánszemélyek részére a hajózási jogot és a halászati jogokat. Felmerült, hogy ez a tulajdon a forradalommal (vagyis a függetlenség elnyerésével) az Amerikai Egyesült Államokhoz került. A bíróság ezen az állásponton maradt. A tanulmány ismerteti még az USA judikatúrájából az Arnold v. Mundy (1821), a Martin v. Waddel's Lessee (1842), a Railroad v. Illinois (1892), az Illinois Central R. R. v. Illinois (1916) ügyeket is a public trust szempontjából.

Alistair Cole, a Cardiffi Egyetem oktatója az Egyesült Királyságban meglévő területi feszültségek témakörét dolgozta fel. Ennek címe: Les tensions territoriales au Royaume-Uni (Perroud, 2017:105-116). Köztudomású, hogy az Egyesült Királyság Európa egyetlen országa, amelynek alkotmánya íratlan, azaz történeti, ami a közjóval kapcsolatos történeti tapasztalatok jelentôségét támasztja alá, szemben az írott (kodifikált, egyetlen alkotmánylevélben összefoglalt) alkotmányokkal. A parlamenti szuverenitás doktrínája és a parlamentarizmus westminsteri rendszerének hatásai érezhetőek a helyi önkormányzatok és a területi államigazgatás terén. Angliában a helyi hatalom a központi hatalomnak alárendelt. A parlament adja át a hatásköröket a helyi önkormányzatoknak, mind a kötelezô, mind a szabadon (önként) vállalható feladatok vonatkozásában. Az ultra vires elve logikusan következik a parlamenti szuverenitás elvébôl. Anglia korábban történetileg a helyi demokrácia országa volt, mindez hosszú századok politikai fejlôdésének gyakorlati irányultságú öröksége. Az angolban a gondviselô állam (État providence à l'anglais) kifejezés a helyi (köz) politizálás (action publique locale) hagyományából ered. 1983-ban született meg a kettôs állam (État dual) elmélete Bulpitt gondolatiságában, amely szerint az országos ügyeket (affaires nationales) London kezeli, míg a helyi ügyeket az adott helyi önkormányzatok. A múködésbeli egymásrautaltság mind a „magas,” az országos politikában, mind a helyi politikában létezik, bár kevésbé formálisan. A mandátumhalmozás hagyománya úgyszólván nem létezô, az állam területi szolgáltatásnyújtásainak többsége rendkívüli módon gyenge vagy nem létezô, kivéve Skóciát, Walest (Pays de Galles) és Észak-Írországot. Cole szerint Bulpitt elmélete a londoni közigazgatási-politikai elit elmélete, nem pedig a községeké, régióké vagy kisebbségi nemzetiségeké. Ezen modell alapján az elit számára a központon kívüli területek érdektelenek, mivel a központi közigazgatási-politikai elit és a kelta perifériák (kelta, azaz skót, ír, walesi, cornwalli, Man szigeti „végek” - $K$. Gy.) között kisebb a kapcsolat. Mindebben változást Margaret Thatcher 1979 és 1990 közötti regnálása hozott. Cole meglátása szerint a területi közeledést a New Public Management állama (État managerial) hozta el a kettôs állam koncepciójával szemben. 2007-tôl a devolúció hajtómúvévé Skócia vált a Skót Nemzeti Párt gyôzelmével (2011ben és 2016-ban is győztek). A 2014-es Alec Salmond-féle függetlenségi terv és függetlenségi népszavazás egyelőre szônyeg alá lett söpörve.

John F. McEldowney, a Warwicki Egyetem jogászprofesszora a közjogi szabályozás angol és francia módozatait vetette egybe angol nyelvú tanulmányában. Ennek címe: Comparative aspects of public law regulation: an Anglo-French analysis (Perroud, 2017:877-892). 
Koi Gyula: Gérard Marcou és az összehasonlitó közigazgatási anyagi és eljárásjog II.

A globalizáció és a vele járó közigazgatási-kormányzati megacentralizáció számos demokráciában növelte a távolságot a nép és a kormány között. A 2008-as gazdasági válság kimutatta, hogy számos gazdaság sérülékenysége adott a nemzetközi bankrendszerrel szemben, amely felett egy minimális kontroll szükséges. A megszorító intézkedések számos emberben bizonytalanságot keltettek a szervezeti struktúrákkal szemben. Mind Franciaországban, mind az Egyesült Királyságban a politikai forgatókönyvekben levonták a nyugat-európai megszorítások és a hosszú recesszió tanulságait. A szabályozó állam (regulatory state) felemelkedése számos szerzó által előre jelzett volt, és a szabályozási rendszerek alkalmazkodtak a globális pénzügyi válsághoz. A kiadások csökkentése, az adóemelés, az állam szerepének megnövekedése, az erôforrások allokációjával kapcsolatos reformok és a közszolgáltatások nyújtásával kapcsolatos felelôsségi rendszer változásai adva vannak. A helyi önkormányzatok szerepe is jelentôs ebben a folyamatban, különösen a központi és a helyi szint közötti erőforrás-allokáció vonatkozásában. Az állam változó jellemzôi ellenére az államhatalom szerepe fontos marad.

Isabelle Muller-Quoy, aki az amiens-i Jules Verne Egyetem adjunktusa közjogból (továbbá még három egyéb intézményben van affiliációja), az Amerikai Egyesült Államok helyi igazgatását vizsgálta. Munkája címe: L'autonomie locale aux États-Unis (Perroud, 2017:303-314). Az Amerikai Föderáció alkotmánya mit sem említ a helyi önkormányzatokkal kapcsolatosan, bár közel kilencvenezer helyi önkormányzat van az Amerikai Egyesült Államokban. Erre csupán a tizedik alkotmánykiegészítésben került sor. A kormányzati hatalomhoz képest a helyi önkormányzatok az államok alkotásai. A helyi önkormányzatok valós helyzete az államok, illetve a föderális állam akaratától függ (decentralizáció). Ebben a Home Rule törvénynek és a Dillon-elvnek is nagy a szerepe.

A POSzTSZOGIALISTA RENDSZER：OROSZ ÉS EGYÉB PÉLDÁK

Christophe Samuel Hutchinson, az Orosz Föderáció Kormánya mellett múködô Pénzügyi Egyetem Gazdasági Jogi Tanszékének tudományos munkatársa az orosz jog célkitűzéseit és eszközeit vizsgálta amerikai és európai joggal kapcsolatos egyezmények tükrében. Ennek címe: Les objectifs et instruments du droit russe en matière d'ententes au regard des droits américain et européen (Perroud, 2017:495-518) Az amerikai kartelljog (droit antitrust américain, az egyéb nyelvi ekvivalensekre: Koi, 2017:1-4) elôször a Sherman Act (1890) keretei között jelent meg. Ez a szabályozás a szabad verseny védelmét, illetve a gazdaság szabadságát volt hivatott szolgálni. Az 1957-es római szerződésben az Európai Közösséget alapító hét állam megállapodott a közösségi versenyjog alapvetô szabályairól. Az 1993-as orosz alkotmány szintén garantálta a gazdasági verseny, illetve a piac szabadságát. A késôbbi alkotmányi szabályozás jegyében az elsô orosz szövetségi versenyjogi törvény már 1991-ben megjelent (RSFSR). 1991 óta e törvény több mint harminc alkalommal módosult, legutóbb 2017. július 27-én. A törvényszöveg tengelyében (pivot) a gazdasági verseny védelmének elve áll, és ebben egyezik a nagy európai versenyjogi kodifikációs koncepciókkal. Az írás a továbbiakban különféle jogeseteket 
vizsgál, az EU-ból az úgynevezett Fapép- (Pâte de bois) ügyet (1988) - a fapépet gyakran a parmezán sajt helyett, vagy a porfinomságú reszelt termék szaporításához, annak „felütése” céljából, az eredeti mellett alkalmazzák; orosz vonatkozásban az OTP Bank ügyét (2008); orosz és belarusz vonatkozásban egy sókereskedelemmel kapcsolatos, a két ország konfliktusát hozó jogesetet, a Mosirsol-ügyet (2008) vizsgálta.

Vyacheslav Tolkovanov, a Nemzeti Közgazdasági Egyetem professzora az ukrán helyi igazgatási rendszer fejlődésérôl alkotta meg dolgozatát. Ennek címe: Évolution du système de l'autonomie locale en Ukraine: aspects historiques et défis actuels (Perroud, 2017:415-428). Meglátása szerint Ukrajna még az átmenet (transition) állapotában van, ezzel együtt vagy ennek ellenére a közéletben a helyi önkormányzatok helye megszilárdulni látszik, hatáskörük terjedelme nô. A 2004-es narancsos forradalom, illetve a 2013-2014 közötti második Majdan ${ }^{14}$ mozgalom kiváltképpen magára vonta az európai figyelmet Ukrajnát illetôen. A 2014-es új kormány meghirdetett reformprogramjának egyik pontja volt a helyi közigazgatás modernizálása. A társadalmi kohézió, illetve a gazdasági jólét vonatkozásában, továbbá az ukrán állam demokratikus fejlôdésében az ukrán helyi önkormányzatok kiemelt szerepet játszanak. A helyi autonómia és a helyi önkormányzáshoz való jog nem csupán az önkormányzatok felelôsségét jelenti, hanem közigazgatási, pénzügyi és múszaki-technikai eszközök alkalmazását. Azonban a helyi népszavazások és a helyi vezetôk vonatkozásában problémák vannak, fóleg a döntések függetlensége és törvénynek való alárendeltsége vonatkozásában. A szovjet elmélet alig tett különbséget a közigazgatási dekoncentráció és a politikai decentralizáció között, és mindez máig érezteti a hatását. Ezt követôen olvashatunk az autonómia szó részletes etimológiai elemzésérôl. Ehhez hasonló az önkormányzat angol (self-government) és német (Selbstverwaltung) koncepciója. Az ukrán folyamatokat történeti keretbe helyezve, a modern fejlődést előtérbe állítva 1990-tôl 2000-ig elemzi a szerzó.

Khayadarali Yunusov a taskenti Világgazdasági és Diplomáciai Egyetem profeszszora, aki a francia és üzbég kétkamarás parlamentek hatáskörmegosztását vizsgálta. Ennek címe: La distribution des compétences entre les chambres dans le bicaméralisme: étude comprative sur l'expérience de l'Ouzbékistan et de France (Perroud, 2017:1169-1180). Míg az 1970-es években csupán 45 kétkamarás parlament volt, ez a szám már 80 felettire módosult. Üzbegisztánban a kétkamarás parlamentet 2005-ben vezették be. A kétkamarás parlamenttel bíró államok nagy része unitárius államban található, ezek közé tartozik Franciaország és Üzbegisztán is. 2010-ben Üzbegisztán jelentôs államreformot vezetett be, és sor került a hatalmi ágak közötti hatáskör újraelosztására. Az elemzés a hasonlóságok között említi, hogy mindkét ország unitárius államszerkezetú, és a parlamentjeik kétkamarásak. Mindkét állam esetében a törvényalkotási folyamat során a parlamentek aktív szerepet játszanak, akárcsak a kormány ellenôrzésében, és jelentős a vegyes paritásos bizottságok szerepe is. A parlamentek szerepe mindkét országban fontos az egyes állami tisztségviselók jelölési jogát, illetve az állam múködésének alakítását illetôen.

Balázs István, a Debreceni Egyetem professzora, az MTA Társadalomtudományi Kutatóközpont Jogtudományi Intézete tudományos főmunkatársa, az intézet Közigazgatási Jogi Kutatócsoportjának vezetôje a magyar helyi önkormányzatiság fogalmának új tendenciáiról írta tanulmányát (Balázs, 2017:69-76). A 2010 óta hatalmon 
Koi Gyula: Gérard Marcou és az összehasonlító közigazgatási anyagi és eljárásjog II.

lévố magyar kormány a közigazgatást recentralizálja. Mindez a szerzô szerint a helyi önkormányzatok autonómiájának csökkenésével jár együtt. A változások mögött korunk szükségleteinek, illetve a globalizációs (mondialisation) válságok kihívásaira adott válaszként az államhatalom megerôsítésének, az államigazgatás helyreállításának filozófiája húzódik meg, az emberek érdekeinek védelme, valamint az ország versenyképességének megőrzése szándékával együtt. Ezek reális célkitûzések, bár Balázs István úgy látja, hogy az elmúlt öt évben alkalmazott eszközök nyomán hozott intézkedések vitathatóak, fóként a helyi önkormányzati reformok vonatkozásában. A 2011. április 25-i új magyar alkotmány, az Alaptörvény ${ }^{15}$ 2012. január 1. óta a korábbitól eltérô módon szabályozta a helyi önkormányzatok jogi helyzetét. A korábbi alkotmányos megfogalmazások részletekbe menóen szabályozták és egyben garantálták a helyi autonómiát. A helyi önkormányzatokról szóló 2011. évi CLXXXIX. törvény valósította meg sarkalatos törvényként a részletszabályokat. A dolgozat az új szabályozás fố vonalainak bemutatását foglalja magában.

\section{A KÍNAI ÉS EGYÉB ÁZSIAI RENDSZEREK}

A Kínai Népköztársaság közigazgatási bíráskodásáról a Kínai Állam- és Jogtudományi Egyetem adjunktusa, Wei Wang írt. Anyaga címe: Le rôle du contentieux administratif en Chine: un régulateur des pouvoirs publics (Perroud, 2017:1049-1060). A kínai jogi hagyománytól idegen a közigazgatási bíráskodás eszméje. Az igazgatottak többnyire nem kérdőjelezik meg a közhatalmi döntéseket. (Megjegyzendő, hogy nézetem szerint ez még császárkori, konfuciánus tradíció.) 1989 óta van jelen a közigazgatási bíráskodás a jogállami (État de droit) fejlódés fontos elemeként. A közigazgatási bíráskodás gyakorlatában 1989-ben a megszokotthoz képest három eltérố elemet találunk: eltérô a közigazgatási bíráskodáshoz való hozzáférés; problematikus a fellebbezés, illetve eltérőek a közigazgatási tárgyú ítéletek körében a végrehajtási szabályok. Ezen eltérések orvoslása érdekében a kínai Népi Gyúlés (a parlament) 2014-ben a közigazgatási bíráskodásról szóló törvényt illetôen fontos módosításokat léptetett életbe. 2016-ban a szerzô a módosítást illetôen általánosságban pozitívnak látta a mérleget, hasonlóan az elméleti múvelők és a gyakorlatban dolgozó bírák véleményéhez, még ha bizonyos problémák továbbra is fennálltak. A közigazgatási bíráskodással foglalkozó kutatások nagy része magában foglalta az igazságszolgáltató hatalommal kapcsolatos szabályozás hatásának mérését a közigazgatási szervek (pouvoir administratif) vonatkozásában, ideértve a közigazgatás és az igazgatottak közötti kapcsolatot is. A központi hatóságok és a helyi igazgatás kapcsolatát illetôen a közigazgatási bíráskodás nem kapott eleddig kellő figyelmet a Kínai Népköztársaságban. A központi hatóságok a helyi önkormányzatok ellenôrzése során azt a módszertant alkalmazzák, hogy az egyes magasabb vezetôket mozgatják a szintek és a régiók között, azaz az igazgatás eltérô szintjein, az ország eltérô területein, régióiban alkalmazzák ôket (azaz változó szolgálati helyeken). Így a központi hatalmi kényszer jelenléte minden szinten biztosított az ellenôrzés során, valamennyi közigazgatási szerv esetében. Ahogy egyes kutatók megállapítják, Kínában a föderalizmus tényszerúen elismert, figyelembe véve az állam struktúráját és a helyi ön- 
kormányzatokat. A tanulmány külön vizsgálja az igazságszolgáltatás közigazgatási szervek feletti ellenôrzését, az állam, illetve a helyi önkormányzatok kapcsolatát egyaránt.

Shigeru Yamashita, a tokiói Meiji Egyetem professzora a japán helyi önkormányzatok karakterisztikáját angol nyelven, nemzetközi összehasonlításban vizsgálta. Ennek címe: Japan's local government system - an overview of main characteristics from a viewpoint of international comparison (Perroud, 2017:459-480). A dolgozat a jelenlegi (current) japán helyi önkormányzati rendszer jellemzóit, karakterisztikáját, múködési leírását igyekszik feltárni. Ennek során a francia, az egyesült királysági, a német, illetve az USA-beli példákkal veti össze Japán helyi önkormányzatának rendszerét. Külön kiemelendô, hogy a Japán Helyi Önkormányzatok Nemzetközi Összehasonlítása céljából és névvel alakult társaság (Japan's Council of Local Authorities for International Relations; Associations des Collectivités Locales au Japon; röv.: CLAIR) honlapján (http:// www.clair.or.jp) a témában angol és francia nyelvú tanulmány áll rendelkezésre. Az összehasonlítást igen átgondolt, sok szempontú (25 elemú), professzionális táblázat segíti (Perroud, 2017:460-461), mely igen értékes, bár részben szükségképpen szimplifikatív contributio. Ez alapján a fố megállapítása a tanulmánynak, hogy Japán jelenlegi helyi önkormányzati rendszere a francia és német, valamint az USA önkormányzati rendszerének hibridje, „kevercse.” Emlékeztet rá, hogy ez a rendszer a Meiji császár-féle reformok eredményeképpen, az 1880-as évektôl, francia és porosz hatásra alakult ki. A második világháborút követôen történeti okokból az amerikai hatások erôsödtek fel, és az 1946-os (egyébiránt oktrojált - K. Gy.) japán alkotmány mellett 1947-ben egy helyi önkormányzati kódexet (Local Government Code) is elfogadtak, mely inkorporálva egyes amerikai megoldásokat, hibrid rendszert hozott létre: francia-porosz alapokon álló, USA-irányultságú jogalkotási terméket, japán stílusú módosításokkal. A tanulmány további részei e rendszert ismertetik közigazgatási jogi, közszolgálati jogi, választójogi, pénzügyi szempontokból. Három szépirodalmi példát is hoz a változások megvilágítására. Az elsố kettô a Gulliver (Swift, 1726), ${ }^{16}$ illetve Hófehérke (Snow White, vö. Grimm-Grimm, 1812:264-273 $)^{17}$ története adta párhuzamot használja fel. A Gulliver-típusú területszervezési modell azt a reformjavaslatot jelentette, amelynek alapján az angol county méretú japán területi egységet (ken) magasabb szintre (wider tier) emelve, új régiós rendszert vezettek volna be. Így a mi fogalmaink szerinti középszint kiesésével az alapszintú község és város mellett a régiók maradtak volna meg, ezt hívja a japán szakirodalom a liliputiaknak és Gullivernek, vagyis Gulliver-típusú modellnek (Gulliver-type intergovernmental relations). Az alapszintû, nagyobb, illetve „szupernagy” területi egységek bevezetése pedig a Hófehérke és a hét törpe képzetét keltette a japán tudósokban, a területek méretbeli eltérései miatt (Hófehérke-típusú modell; Snow White-type intergovernmental relations). A harmadik a Gendzsi szerelmei, ${ }^{18}$ a híres, nagyjából 1000 és 1020 között Muraszaki udvarhölgy által íródott, japán nagyepikus (epopeia) regényfolyam ${ }^{19}$ példáját használja fel. Itt a japán modernizáció lehetôségeit különbözô japán történeti példákon vezeti le Yamashita. A 11. században a Gendzsi-regény 21. fejezetéból veszi a példát, amely szerint a kínai típusú tanulmányokat a japán szellemmel kell elegyíteni. ${ }^{20}$ Mindenesetre az írás a japán helyzet megismerését illetôen rengeteg tanulsággal szolgál. 
Koi Gyula: Gérard Marcou és az összehasonlító közigazgatási anyagi és eljárásjog II.

Kwangyoun Lee, a szöuli Sungkyunkwan Egyetem professzora a nukleáris energia és a dél-koreai jogállam kapcsolatát írta le tanulmányában. Írásának címe: L'énergie nucléaire et l'État de droit en Corée (Perroud, 2017:3-12). Dél-Koreában jelenleg 23 atomreaktor 20,5 GW elektromos áram termelésére alkalmas évente. Ez Dél-Korea éves villamosenergia-felhasználásának 22\%-át fedezi, ám ez a kapacitás 29\%-ra lenne emelhetô, a tervek szerint 2035-ig. Azonban az elképzelések szerint a jelenlegi 20,5 GW-ot 43 GW-ra törekednek emelni a távolabbi jövőben. Ezeket a törekvéseket kisebb nukleáris események (petits accidents) gátolták a Hanul és a Gori erőmúvekben. Tény, hogy a sugárzásveszély (risque de rayonnement) Dél-Korea esetében is fennáll. A tanulmány további részei az alkotmányban adott szabadságokat (egészséghez való jog, a katasztrófák megelőzésének kötelezettsége az állam részérôl), illetve a jogi és a közigazgatási környezetet és kultúrát is elemzi. A probléma nem feltétlenül a jogban gyökeredzik, de a köztisztviselői-közhivatalnoki tényleges gyakorlat, illetve a munkások alacsonyabb helyzete (position inférieure des travallieurs) a tekintélyelvú közigazgatási kultúra megváltoztatását kívánja. A dolgozat külön nem mondja ki, de az atomenergiára vonatkozó eljárást nem az 1996-ban elfogadott általános közigazgatási eljárási törvény szabályozza, hanem a 2015-ös atomenergia-törvény ${ }^{21} 103$. §-a, igen bonyolultan. Konklúziója, hogy az e kérdésekben való döntés a központi igazgatás diszkrecionárius jogköre. Ugyanakkor a lakosság nem tárgya a közigazgatásnak, és az atomenergia-ügyi döntéseket rájuk tekintettel kell meghozni. Tény, hogy a lakosság részvétele ezen ügyekben korlátozott, így az atomenergia-igazgatással foglalkozó szerv vezetôje köteles a lakossággal, illetve a központi igazgatással és a helyi önkormányzatokkal is együttmúködni az ügyben.

In Soo Park a dél-koreai nemzetgyúlés tárgysorozatba vételi rendjérôl szóló írását publikálta a kötetben. Ennek címe: La fixation de l'ordre du jour à l'Assemblée nationale en Corée (Perroud, 2017:25-34). A tárgysorozatba vétel, azaz a Nemzetgyúlés napirendje (ordre de jour), múködése a kormánypárt és az ellenzék vitáitól és megállapodásától függ. Mindez igen jelentékeny súllyal bír a törvényhozás múködését illetően. A tárgysorozat rögzítése az 1940-es években történt meg először. A továbbiakban a tanulmány az alábbi lehetséges elképzeléseket vázolja: a Napirendi Bizottság megszüntetése a Nemzetgyúlés elnöke által; különbizottság létrehozatala a napirend rögzítésére; a végrehajtó hatalom szerepének erôsítése a törvényalkotási eljárásban. Az ezen megoldások közötti választás lehet a gyógyír a problémákra.

\section{AZ AFRIKAI RENDSZEREK PÉLDÁJA}

Jacques Fialaire, a Nantes-i Egyetem közjogi professzora, a GRALE társigazgatója az észak-afrikai frankofón államok nagyvárosi szerkezetét dolgozta fel. Ennek címe: L'organisation des métropoles dans les États d'Afrique noire francophones (Perroud, 2017:207-222). Mezőgazdasági és agrárkontinensként Fekete-Afrikában (szubszaharai Afrikában) az urbanizáció, illetve a túlnépesedett nagyvárosok okoznak problémát. (A nagyvárost a szerzó a közismert ENSZ-definíció alapján értelmezi.) Az afrikai problémák vizsgálatakor a szerzố áttekinti a jogi és intézményi konstrukciók szerepét; valamint az afrikai nagyvárosok fejlődésének analízisét is elvégezte. 


\section{Polgári Szemle · 15. évfolyam 4-6. szám}

\section{JEGYZETEK}

1 Készült az Eötvös Loránd Kutatóhálózat Jogtudományi Intézete Közigazgatási Jogi Kutatócsoportján belül A magyar jogrendszer reakcióképessége 2010-2018 elnevezésú NKFIH kutatási fôiránya (2019-2021) keretében.

2 Paul Pradier Fodéré (1827-1904) strasbourgi francia jogtudós, kezdetben párizsi ügyvéd, 1857-tôl a velencei Collegio Armeno Moorat, majd a párizsi École des sciences politiques tanára. 1857-tôl a perui Limai Egyetem Államtudományi Tanszékének tanára. Késôbb a lyoni Felsôbíróság bírája. Précis de droit administratif (1853) címmel írta meg a közigazgatási jogi munkáját. A közigazgatási jog mellett jogelméletról, nemzetközi jogról, kereskedelmi jogról és a politikai jogokról is írt francia nyelven. Napjainkra jóformán Franciaországban is ismeretlen a személye, emlékét amerikai, német és orosz nyelvú lexikonok órizték meg.

3 A francia döntés szövegének rövid összefoglalására a brazil szerzố nem utal. A Jordão-féle nézôpont arra sem utal, hogy a döntés ahhoz az Édouard Laferrière-hez köthetô, aki nemcsak (több elôdjéhez hasonlóan) elméleti jogmúvelô és professzor, hanem államtanácsos is volt (késôbb az Államtanács alelnöke 1886 és 1889 között), aki alapmúveivel befolyásolta annak ítélkezését. A francia tudományosság a modern francia közigazgatási jog atyjának tartja. Ilyen volt német területen Otto Mayer, az olasz területen Vittorio Emanuele Orlando, az angolszász közigazgatási jog területén pedig Frank Johnson Goodnow. Fố múve: Laferrière, 1887-1888. Édouard Laferrière szerepére lásd Koi, 2014:76-77.

4 Gaston Jèze a service public elmélet egyik vezetố tudósa, a bordeaux-i iskola vezetôje; munkásságára lásd Koi, 2014:261-262.

5 Azaz az Afrikát megkerülő, Amerikába tartó ázsiai hajóutak spanyol függés alatt álló területeinek joga (India névvel illették hajdan Ázsia egészét).

6 A német eredetû elvet nálunk változatlanul Concha Gyốzô foglalta össze legjobban, a mai napig fố mûve elôszavában: „Hisz a közigazgatás semmi egyéb, mint az alkotmány gyakorlata. Ami az alkotmány kitúzte célból a közigazgatás által valósággá lenni nem tud, az vagy általában utópia, vagy az illetô nemzet gyengeségének jele" (Concha, 1905:III.).

7 „Le droit comparé de domaine public reste encore à inventé... et un fois de plus, il est plus developpé en Allemagne qu'en France, les Allemands ayant une meilleure maîtrise du droit administratif français des biens, que les Français du droit [administratif-K. Gy.] allemand."

8 A legfontosabb (alapvetốen német nyelvú) alapmúvek idôrendben: Meier, 1907-1908; Heyen, 1989; Beaud-Heyen, 1999.

9 „Die gesamte staatliche Verwaltung darf nur auf Grund der Gesetze ausgeübt werden.” „L'administration publique tout entière ne peut être exercée que sur la base des lois."

10 Még az oly megbízható Hachette-szótár sem ismeri: Guérard, 1980.

11 A porosz uralkodócsalád tagjai, ahogy a Habsburgok is, még a 18. század végén is franciás múveltségúek (is) voltak, egymás között a családtagok francia nyelven leveleztek. Erre példa Habsburg Sándor Lipót fôherceg nádor és édesapja, II. Lipót magyar király francia korrespondanciája, erre lásd Mályusz, 1926:431-449 (43-47. sz. levelek). A hivatalos levelezés németül és franciául folyt, Habsburg Sándor Lipót II. Lipóthoz küldött német leveleiból lásd Mályusz, 1926:258-260, 261-263 (4-5. sz. levelek).

12 „Ich... stabiliere die Souveränität und setze die Krone fest wie einen rocher von bronze.” Azaz: „Rendíthetetlen kôsziklaként megôriztem a népfelséget és a koronát.” Az idézet forrása Meyer, 1909:38. Értelem szerint a tanulmány szövegének hermeneutikai tartalmára tekintettel inkább gránitszilárdságúként adtuk vissza a kifejezést.

13 Eörsi a jogelméleti vetületeket mutatja be. Almén múve a magánjogon belül a svéd vételi jog történeti sajátosságainak és más nemzetek hasonló joganyagával történô összevetésének máig legjobb összefoglalása.

14 Майдан Незалежності (Majdan Nežalenosti), azaz a Függetlenség tér mint helyszín neve alapján terjedt el a „Majdan” kifejezés.

15 Megjegyzendô, hogy az elnevezéshez sem a német Grundgesetz (1949), sem a holland Grondwet (1814) nem szolgált mintául, a leges fundamentales a történeti alkotmányos hagyományok egyik bevett múszava volt (a sarkalatos törvénnyel együtt - leges cardinales). Vö. Toldy, 1861. 
Koi Gyula: Gérard Marcou és az összehasonlitó közigazgatási anyagi és eljárásjog II.

16 A Gulliver utazásaiként (Gulliver's Travels) ismert alapmú eredetileg a szerzô feltüntetése nélkül jelent meg, a jelenleg ismerttốl eltérô címmel.

17 Elsố írásos közzététele a Grimm testvérek gyújteményében történt: Grimm-Grimm, 1812:264-273.

18 Korai és modern japán szöveg párhuzamba állított verziója: Murasaki, 1999:5-1561.

19 A mú japán irodalomban elfoglalt kiemelt jelentôségére lásd Seidensticker, 1974:56-59. A szerzô japán filológiával foglalkozott, a regény legjobb angol fordítását készítette. A japán irodalomtörténetre lásd Vihar, 1994:22-26. Muraszaki életének részben történeti, részben írói rekonstrukciója az egyetlen japán gésa és írónő tollából: Dalby, 2007:15-405.

20 Ez részben utólagos értelmezés, a fejezet idevonatkozó vezérgondolata így hangzik: „A világ a japán szellemet csak akkor tiszteli, ha kínai tudományból van az alapja.” Közigazgatás-tudományi szempontból sem érdektelen azonban továbbolvasnunk, ugyanis Gendzsi herceg egyetemre küldi a fiát, és a felvételi vizsgán elhangzik egy megjegyzés az államtudományok vonatkozásában is. „A felvételi vizsgát a nindzsói keleti lakban tartották, ahol a keleti szárnyat rendezték be erre az alkalomra. Ritka esemény volt ez. Udvaroncok özönlöttek, hogy lássák, milyen is egy felvételi vizsga. A professzorok igencsak megdöbbenhettek. - Bánjatok vele [ti. Gendzsi felvételizô fiával, Júgirivel - K. Gy.] úgy, ahogyan a szabályok elốríák - mondta Gendzsi. - Csak semmi kivételezés. Az egyetemi gyülekezet igencsak különös volt, komor képú alakok rosszul szabott kölcsönruhákban, humortalan beszédúek, ám meglehetôsen tolakodóak. A fiatal udvaroncok közül többen kinevették őket. Gendzsi valami ilyesmitől tartott, amikor úgy rendelkezett, hogy a professzorok csészéit idôsebb, komolyabb emberek töltögessék. [Az e célból kijelölt - K. Gy.] Tó no Csúdzsót és Mimbo herceget ennek ellenére megfeddték a tudós urak. - Módfelett inadekvátak ezek az italnemú-töltögetôk! Bölcsek tanácsa nélkül ôk akarnak államügyeket irányítani! Ez módfelett inadekvát!” A japán szöveg angolra fordítója, Edward G. Seidensticker a tudósok szavairól az alábbiakat jegyezte meg: „A professzorok itt következô mondatai mesterkéltek, konfuciánus tónusúak, olyan szavakat tartalmaznak, melyek sehol máshol nem fordulnak elố a múben.” Az államügyekre való utalás azt is jelzi, hogy a konfuciánus kínai tudósok, akikrôl japán társaik a példát vették, a jövố közigazgatási szakembereit képezték, akiket a császárkori Kínában írásbeli versenyvizsgákon válogattak ki, majd konfuciánus filozófiai szövegekkel vérteztek fel, amely akkor a múvelt emberek sajátja volt, és hozzátartozott az írástudók mindennapjaihoz. Ehhez a konkrét igazgatási tudást a gyakorlatban (illetve segédkönyvekből) kellett megszerezni. Muraszaki, 2009:88, fószöveg és 2. lábjegyzet.

21 Hazai érdekesség, hogy az atomenergiáról szóló 1980. évi I. törvény (hatályon kívül) egyetlen kodifikátor, Tamás András alkotása. Ekkoriban nagyjából 20 kodifikátor dolgozott az Igazságügyi Minisztériumban.

\section{FELHASZNÁLT IRODALOM}

Almén, Tore (1922): Das skandinavische Kaufrecht. Ein Kommentar zu den skandinavischen Kaufgesetzen unter eingehender Berücksichtigung ausländischen Rechts I-III. Carl Winter, Heidelberg.

Balázs István (2017): Des nouvelles tendances du concept de l'autonomie locale en Hongrie. In: Perroud, Thomas et al. (eds.) (2017): Mélanges en l'honneur du Professeur Gérard Marcou. Institut de recherche juridique de la Sorbonne - Université Paris I Panthéon, Paris-Millaud, 69-76.

Baulny, Dominique - Laferrière, Edouard (1875): No. 47544 lecture du vendredi 26 novembre 1875. www. legifrance.gouv.fr/affichJuriAdmin.do?idTexte=CETATEXT000007633030.

Beaud, Olivier - Heyen, Erk Volkmar (1999): Eine deutsch-französische Rechtswissenschaft? Kritische Bilanz und Perspektiven eines kulturellen Dialog. Une science juridique franco-allemande? Bilan critique et perspectives d'un dialogue culturel. Nomos, Baden-Baden.

Concha Gyôzó (1905): Politika II. Közigazgatástan. Grill Károly Könyvkiadóvállalata, Budapest.

Dalby, Liza (2007): Muraszaki meséje. Ulpius-ház, Budapest.

Eörsi Gyula (1974): Bevezetés a skandináv jogba és jogtudományba. MTA Állam- és Jogtudományi Intézet, Budapest.

Fehér István (1988): A magyarországi németek kitelepitése 1945-1950. Akadémiai Kiadó, Budapest.

Guérard, Françoise (ed.) (1980): Dictionnaire Hachette de la langue française. Hachette, Paris. 
Grimm, Jacob - Grimm, Wilhelm colls. (1812): Schneewitchen. In: Grimm, Jacob - Grimm, Wilhelm: Kinder- und Hausmärchen I. Realschulbuchhandlung, Berlin.

Heyen, Erk Volkmar (1989): Profile der deutschen und französischen Verwaltungsrechtswissenschaft 1880-1914. Klostermann, Frankfurt am Main.

Jordão, Eduardo (2016): Le juge et l'administration. Entre le contrôle et et la déférence. Bruylant, Bruxelles.

Koi Gyula (2014): A közigazgatás-tudományi nézetek fejlôdése. Külföldi hatások a magyar közigazgatási jog és közigazgatástan múvelésében a kameralisztika korától a Magyary-iskola idôszakáig. Nemzeti Közszolgálati és Tankönyv Kiadó, Budapest.

Koi Gyula (2017): A Kínai Népköztársaság versenyjogának egyes jellemzôi, tekintettel a kartellellenes törvényre. Lezárva: 2013. január 1., Széchenyi István Egyetem ÁJDI, Gyốr.

Laferrière, Édouard (1887-1888): Traité de la juridiction administratives et des recours contentieux I.-II. Hachette, Paris.

Lốrincz Lajos (2005): A közigazgatás alapintézményei. HVG-ORAC, Budapest.

Mályusz Elemér (1926): Sándor Lipót föherceg nádor iratai. Magyar Történelmi Társulat, Budapest.

Meier, Ernst (1907-1908): Französische Einflüsse auf die Staats- und Rechtsentwicklung Preussens im XIX. Jahrhundert I. Prolegomena. II. Preussen und die französische Revolution. Duncker und Humblot, Leipzig.

Meyer, Hermann Julius (1909): Rocher de bronze [Stichwort]. In: Meyer, Hermann Julius: Meyers grosses Konversations-Lexikon. Ein Nachschlagewerk des allgemeinen Wissens XVII. Bibliographisches Institut, Leipzig.

Murasaki, Shikibu (1999): Genji monogatari I-III. University of Virginia, Charlottesville.

Muraszaki, Sikibu (2009): Gendzsi szerelmei II. Európa Könyvkiadó, Budapest.

Perroud, Thomas et al. (eds.) (2017): Mélanges en l'honneur du Professeur Gérard Marcou. Institut de recherche juridique de la Sorbonne - Université Paris I Panthéon, Paris-Millaud.

Seidensticker, Edward G. (1974): Genji monogatari. How Many People Wrote the Tale of Genji. In: Kafu, Nagai et al. (eds.): An Invitation to Japan's Literature. Japan Culture Institute, Tokyo, 56-59.

Swift, Jonathan (1726): Travels Into Several Remote Nations of the World. In Four Parts. By Lemuel Gulliver, First a Surgeon, and then a Captain of Several Ships I-IV. Benjamin Motte, London.

Tamás András (2011): Svédország közigazgatása. In: Szamel Katalin - Balázs István - Gajduschek György - Koi Gyula (szerk.): Az Európai Unió tagállamainak közigazgatása. CompLex Wolters Kluwer, Budapest.

Toldy (Schedel) Ferenc (1861): Sylloge legum Hungariae fundamentalium. A magyar birodalom alaptörvényei. Az eredeti deák szöveg mellé vetett magyar fordítással, közjogi segédkönyvül. Magyar Királyi Egyetemi Nyomda, Buda.

Vihar Judit (1994): A japán irodalom rövid története. Nemzeti Tankönyvkiadó, Budapest.

Ziller, Jacques (2003): Vrais et faux changements dans les administrations en Europe. Revue Français d'Administration Publique, Vol. 15, No. 105-106, https://doi.org/10.3917/rfap.105.0067. 